\title{
1. Judicial interactions in action - a tool for a more powerful and influential EU Charter of Fundamental Rights
}

\author{
Federica Casarosa and Madalina Moraru
}

\section{THE MULTI-FACETED DIMENSIONS OF THE EU SYSTEM OF PROTECTION OF FUNDAMENTAL RIGHTS}

The multilevel system of fundamental rights protection that applies in Europe may be interpreted as the result of national, regional and international legislators' shared concerns about the protection of rights and principles essential in democratic societies. ${ }^{1}$ However, the normative hierarchy, the overlap and the cross-referencing between national and European bills of rights creates a complex fundamental rights web that is difficult for those willing to put these principles into practice to untangle. ${ }^{2}$

1 A. Barbera, 'Le tre Corti e la tutela multilivello dei diritti' in P. Bilancia and E. De Marco (eds), La tutela multilivello dei diritti: Punti di crisi, problemi aperti momenti di stabilizzazione (Giuffrè, Milano, 2004), $81 \mathrm{ff}$; A. Cardone, La tutela multilivello dei diritti fondamentali (Giuffrè, Milano, 2012); M. Cartabia, "Taking Dialogue Seriously": The Renewed Need for a Judicial Dialogue at the Time of Constitutional Activism in the European Union', Jean Monnet Working Papers 12 (2004); F. Sorrentino, 'La tutela multilivello dei diritti', 2004, available at www .archivio.rivistaaic.it (last visited 20 October 2021).

2 I.E.A. Pernice, 'Multilevel Constitutionalism and the Treaty of Amsterdam: European Constitution-Making Revisited?', Common Market Law Review, 36 (1999), 703 ff.; I. Pernice, 'Multi-Level Constitutionalism and the Treaty of Amsterdam: European Constitution-Making Revisited?', Common Market Law Review, 36(4) (1999), 703. Note that the concept of multilevel structure has been criticised and reformulated by S. Cassese, 'Fine della solitudine delle corti, ovvero il dilemma del porcospino’, Accademia delle Scienze di Torino, Ars interpretandi, 1 (2015), 21. 
The coexistence of multiple levels and decision-making centres, ${ }^{3}$ generating a sort of multilevel governance, has on the one hand undermined classic institutions such as sovereignty and the protection of rights as an absolute State prerogative; on the other hand, it has pushed forward the process of European integration. Safeguarding and guaranteeing fundamental rights therefore take place between the different layers of this system without, however, completely coinciding with them. ${ }^{4}$ In Europe, this integrated system of protection of fundamental rights includes the supranational level (represented by the European Convention on Human Rights (ECHR), the case law of the European Court of Human Rights (ECtHR) and the EU Charter of Fundamental Rights as well as the case law on fundamental rights of the Court of Justice of the European Union (CJEU)) and the national level. ${ }^{5}$ The integration of these levels results in a multilevel protection of rights comprising constitutionally recognised rights, those protected by the Convention and those provided for in the EU Charter.

This 'inter-constitutional order' finds its main legitimisation in the national constitutions, which become 'inter-constitutions': charters that are open to international declarations which can also offer effective contributions to the full safeguarding of the fundamental values of freedom and equality. ${ }^{6}$ Consequently, constitutional provisions addressing fundamental rights cannot be disentangled from the interpretation of these rights provided by the Strasbourg and Luxembourg courts. ${ }^{7}$

Within this system, the EU Charter stands as a recent addition. The Charter's entry into force a little more than a decade ago allowed legal practitioners to explore - although still timidly - the potential of this bill of rights to resolve cases involving a violation of fundamental rights. ${ }^{8}$ However, this did not happen smoothly as several doubts emerged during this period, in particular

3 M. Luciani, 'Costituzionalismo irenico e costituzionalismo polemico', Giurisprudenza costituzionale, IV (2006), 1660.

4 A. Ruggeri, "La tutela "multilivello" dei diritti fondamentali, tra esperienze di normazione e teorie costituzionali', Politica del diritto, 3 (2007), 317.

5 D. Tega, 'La Cedu e l'ordinamento italiano' in M. Cartabia (ed.), I diritti in azione: Universalità e pluralismo dei diritti fondamentali nelle Corti europee (il Mulino, Bologna, 2007), 68.

6 A. Ruggeri, 'Sovranità dello Stato e sovranità nazionale, attraverso i diritti umani, e le prospettive di un diritto europeo "intercostituzionale", Rivista di diritto pubblico comparato ed europeo, fasc. 2 (2001), 544.

7 A. Ruggeri, 'La tutela "multilivello" dei diritti fondamentali, tra esperienze di normazione e teorie costituzionali', cit., 129.

8 According to FRA, 'references to the Charter in national courts' decisions are growing more frequent and less superficial'. In 2019, over 11 per cent of the requests for preliminary rulings contained questions related to the Charter (see FRA, Ten Years On: Unlocking the Charter's Full Potential (Publications Office of the European Union, Luxembourg, 2020), 7). 
regarding: what is the precise scope of application of the Charter compared to the scope of application of EU law ${ }^{9}$ What is the relationship between the rights in the Charter and the general principles of EU law, ${ }^{10}$ the ECHR ${ }^{11}$ and national constitutions? ${ }^{12}$ What are the different forms of justiciability of its provisions? ${ }^{13}$

On many occasions, national courts were unable to disentangle this knot so they sought guidance, directly from the CJEU through the preliminary reference procedure or indirectly through comparative analysis of foreign decisions on similar issues. These vertical and transnational judicial interactions had an immediate impact on the resolution of specific conflicts of interpretation of the EU Charter and at the same time they have influenced the subsequent application of the Charter by other courts in new legal fields. ${ }^{14}$

The number of judicial interactions on the clarification of the Charter has been constantly growing over the last decade, ${ }^{15}$ due to the decentralised and non-hierarchical nature of EU law. National courts as well as EU law courts have sought guidance on how to interpret the new bill of rights, and vertical and transnational judicial interactions have proved to avert inconsistent application of international legal norms and inter-court conflicts. ${ }^{16}$ Also, judicial interactions have covered more and more rights from the EU Charter ${ }^{17}$ and legal areas, including those perceived as pertaining to the core of national procedural autonomy, such as national organisation of courts. ${ }^{18}$ The EU Charter has been at the forefront of judicial interactions addressing the chal-

\footnotetext{
9 C-617/10 Akerberg Fransson ECLI:EU:C:2013:105. For an in-depth analysis, see Chapters 2, 3 and 20 in this book.

10 See more in Chapter 18 in this book.

11 See Article 53(2) EU Charter.

12 C-399/11 Melloni ECLI:EU:C:2013:107; see more in Chapters 5, 6 and 7 in this book.

13 See Article 52(5) and Case C-176/12 AMS ECLI:EU:C:2014:2; see more in Chapter 2 in this book.

14 For cross-sectoral and transnational ripple effects of judicial interactions, see Chapter 18 in this book.

15 FRA, Ten Years On: Unlocking the Charter's Full Potential, cit., 9.

16 On judicial interactions averting conflicts between Constitutional Courts and the CJEU, see the Taricco saga commented on in Chapter 5 in this book; while on judicial interaction averting conflicts between the CJEU, ECtHR and national constitutional courts, see Chapter 15 in this book, discussing the rights of same-sex couples from the perspective of the Romanian Constitutional Court.

17 Such as Article 16, see more in Chapters 3 and 4 in this book.

18 On judicial independence and domestic systems and organisation of judiciary, see Case C-64/16 Associação Sindical dos Juizes Portugueses v Tribunal de Contas ECLI:EU:C:2017:395 and the growing list of cases on judicial independence commented on in Chapters 8 and 9 in this book.
} 
lenges raised by the various crises affecting the EU - economic, ${ }^{19}$ so-called refugee, ${ }^{20}$ rule of law. ${ }^{21}$ In spite of the prolific judicial interactions identified in this book, new challenges to effective judicial interaction are developing, risking to diminish both the quantity and quality of judicial interactions. The rule of law backsliding is endangering effective judicial interactions in multiple ways. First of all, the threat of disciplinary actions ${ }^{22}$ and criminal liability $^{23}$ for addressing preliminary questions to the CJEU has a chilling effect on direct vertical judicial interaction between domestic judges and the CJEU. The long-established right of ordinary courts to interact with the CJEU under Article 267 Treaty on the Functioning of the European Union (TFEU), unrestricted by substantial or procedural limitations set out in national laws, constitutions $^{24}$ or judicial hierarchy, ${ }^{25}$ is under threat, leading the European Commission to lodge infringement procedures to protect the EU right of domestic courts to vertical judicial interaction. ${ }^{26}$ Furthermore, the undermined judicial independence of some domestic courts diminishes the mutual trust which is the stepping stone for efficient transnational judicial interaction under the Area of Freedom, Security and Justice. ${ }^{27}$ In addition to the variable flux

19 Joined Cases C-8/15 P to C-10/15 P Ledra Advertising ECLI:EU:C:2016:701; Case C-258/14 Florescu et al. $v$ Sibiu et al. ECLI:EU:C:2017:448.

20 C-924/19 FMS and others ECLI:EU:C:2020:367.

$21 \quad$ C-585/18 A.K. ECLI:EU:C:2019:982.

22 K. Gajda-Roszczynialska and K. Markiewicz, 'Disciplinary Proceedings as an Instrument for Breaking the Rule of Law in Poland', Hague Journal on the Rule of Law, 12 (2020), 451; P. Bárd, 'Luxemburg as the Last Resort: The Kúria's Judgment on the Illegality of a Preliminary Reference to the ECJ', VerfBlog, 23 September 2019, available at https://verfassungsblog.de/luxemburg-as-the-last-resort/ (last visited 20 October 2021), DOI: 10.17176/20190923-232735-0.

23 See M. Jałoszewski, 'Will Judge Igor Tulea be Apprehended by Force?', (2021), available at https://ruleoflaw.pl/will-judge-igor-tulea-be-apprehended-by-force/\#: $\sim$ :text $=$ Judge $\% 20$ Igor $\% 20$ Tuleya $\% 20$ is $\% 20$ a,harshly $\% 20$ reviewed $\% 20$ the $\% 20$ PiS $\% 20 \mathrm{MPs}$ (last visited 20 October 2021).

24 C-188/10 Melki and Abdeli ECLI:EU:C:2010:363; C-112/13 Av B ECLI:EU:C: 2014:2195; C-416/10 Križan ECLI:EU:C:2013:8.

25 C-210/06 Cartesio ECLI:EU:C:2008:723; C-314/08 Filipiak ECLI:EU:C:2009: 719. For more details see ACTIONES Handbook on the Techniques of Judicial Interactions in the Application of the EU Charter (EUI, 2017), available at https:// cjc.eui.eu/wp-content/uploads/2019/03/D1.1.b-Module-2.pdf (last visited 20 October 2021).

${ }^{26}$ European Commission, 'European Commission refers Poland to the European Court of Justice to protect independence of Polish judges and asks for interim measures', 31 March 2021, Press release, available at https://ec.europa.eu/commission/ presscorner/detail/en/IP 21_1524 (last visited 20 October 2021).

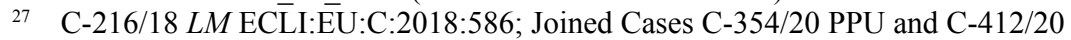
PPU L and P ECLI:EU:C:2020:1033; P. Bárd and J. Morijn, 'Domestic Courts Pushing 
and patterns of judicial interactions, changes are occurring also in the modes of judicial interaction. A new form of judicial interaction emerges - 'abusive comparativism' - whereby captured constitutional courts indirectly interact with the CJEU and ECtHR, by way of a smoke-screened consistent interpretation, to legitimise the constitutionality of 'unconstitutional legislation'. ${ }^{28}$

The various facets, process and outcomes of judicial interaction on the Charter have, so far, not been fully investigated in academic research. Unlike the existing literature, which mostly focuses solely on direct vertical means of dialogue, namely the preliminary reference, ${ }^{29}$ or is limited to particular legal fields, ${ }^{30}$ the contributions in this book analyse the multi-dimensional impact of a wide array of judicial interaction techniques, such as the preliminary reference procedure, consistent interpretation, comparative reasoning, mutual recognition and disapplication, between courts from various jurisdictions, with various specialisations, at various levels in the judicial hierarchy, and over a decade.

The book aims to fill the abovementioned gap regarding the role of judicial interactions in the application of the EU Charter across various fields and jurisdictions. It aims to provide a comparative assessment of selected horizontal and sector-specific legal issues regarding the interpretation and application of

for a Workable Test to Protect the Rule of Law in the EU: Decoding the Amsterdam and Karlsruhe Courts' Post-LM Rulings (Part II)', VerfBlog, 19 April 2020.

28 M. Ziółkowski and B. Grabowska-Moroz, 'Enforcement of EU Values and the Tyranny of National Identity: Polish Examples and Excuses', VerfBlog, 26 November 2019; G. Halmai, 'National(ist) Constitutional Identity? Hungary's Road to Abuse Constitutional Pluralism', EUI Working Paper LAW 2017/08.

29 J. Krommendijk, 'It Takes Two to Tango: An Introduction', European Papers, 5(2) (2020), 745; A. Pahladsingh and R. Grimbergen, The Charter and the Court of Justice of the European Union: Notable Cases from 2016-2018 (Wolf Legal Publishers, Tillburg, 2019); Stacy A. Nyikos, 'The Preliminary Reference Process: National Court Implementation, Changing Opportunity Structures and Litigant Desistment', European Union Politics, 4 (2003), 399-401; Michal Bobek, 'Of Feasibility and Silent Elephants: The Legitimacy of the Court of Justice through the Eyes of National Courts' in Maurice Adams, Henri de Waele, Johan Meeusen and Gert Straetmans (eds), Judging Europe's Judges: The Legitimacy of the European Court of Justice Examined (Hart, Oxford, 2013), 197; Thomas de la Mare and Catherine Donnelly, 'Preliminary Rulings and EU Legal Integration: Evolution and Stasis' in Paul Craig and Grainne de Búrca (eds), The Evolution of EU Law (OUP, Oxford, 2011), 363.

30 Such as M. Moraru, G. Cornelisse and P. de Bruycker, Law and Judicial Dialogue on the Return of Irregular Migrants from the European Union (Hart, Oxford, 2020); D. Baldinger, Vertical Judicial Dialogues in Asylum Cases: Standards on Judicial Scrutiny and Evidence in International and European Asylum Law (Brill-Nijhoff, Leiden, 2015); J. Krommendijk, 'The Preliminary Reference Dance between the CJEU and Dutch Courts in the Field of Migration', European Journal of Legal Studies, 4 (2018), 101. 
the Charter with a profound impact on jurisprudence, legislation and administrative practices at both the EU and domestic levels. In order to provide an overall methodological framework, it is crucial to identify the boundaries of the concept of judicial interactions (section 2) and introduce the book's main research question, namely whether and how judicial interaction techniques employed by courts and judges have solved issues of normative or judicial interpretation incompatibility in a way that has ensured coherence and coordination among different legal and judicial systems in safeguarding human rights in various legal orders (section 3).

\section{JUDICIAL INTERACTIONS: A DEFINITION}

The phenomenon of judicial dialogue between courts at the European and national levels is one of the most interesting topics in contemporary law and it has been widely discussed in the doctrine to the point that, prima facie, it would seem to constitute a subject now widely studied, already exhaustively examined in all its many facets and consequently lacking in food for thought. Numerous pages of literature have been devoted to the topic, and various conceptualisations and applications have developed to the point that it is difficult to find a clear and generally accepted definition, which has further contributed to the development of a diversity of theoretical approaches to judicial dialogue.

At the beginning of the 1990s, the 'dialogue' metaphor was used to describe the use of the so-called comparative jurisprudence method: when a judge examined the case law of other courts, in particular in the field of fundamental rights, it was claimed that the choice of the best solution was the result of dialogue with other courts. ${ }^{31}$ This was referred to as dialogue between different

31 Cfr. C. L'Heureux-Dubè, 'The Importance of Dialogue: Globalization and the International Impact of the Rehnquist Court', Tulsa Law Journal, 34 (1998), 15 ff.; J. Polakiewicz and V. Jacob-Foltzer, 'The European Human Rights Convention in Domestic Law: The Impact of the Strasbourg Case Law in States where Direct Effect is Given to the Convention', Human Rights Law Journal, 12 (1991), 125 ff.; for later literature, see A. Tzanakopoulos, 'Judicial Dialogue as a Means of Interpretation' in H.P. Aust and G. Nolte (eds), The Interpretation of International Law by Domestic Courts: Uniformity, Diversity, Convergence (OUP, Oxford, 2016), 3. 
jurisdictions, ${ }^{32}$ judicial dialogue, horizontal and vertical communication, ${ }^{33}$ transjudicial communication, ${ }^{34}$ interjudicial dialogue ${ }^{35}$ and reception. ${ }^{36}$

As a result of the increasing relations among legal systems - and consequently the increased opportunities for judges in different countries to interact - dialogue between courts was strengthened: references to statements and principles on fundamental rights formulated in foreign jurisprudence flourished. ${ }^{37}$ Moreover, the idea of a 'global legal space' based on common values in which different jurisdictions can interact to solve questions concerning the protection of rights supported this trend..$^{38}$ The idea that 'in fundamental rights there is an aspiration towards universality, which justifies the need to go beyond the boundaries of the individual legal system ${ }^{39}$ is not entirely abstract. The safeguarding of fundamental rights is, in fact, an area of constitutional law common to all legal systems, especially those inspired by the principles of liberal democratic constitutionalism, ${ }^{40}$ and the universal nature of these rights means that they can be interpreted both in the light of national experiences and through comparison with foreign experiences. This in itself fosters dialogue between judges from different countries and the creation of a virtual legal space in which an increasing number of legal systems identify themselves around a common core of principles and discuss the solutions to be adopted in the field of rights.

32 J. Polakiewicz and V. Jacob-Foltzer, 'The European Human Rights Convention in Domestic Law', cit., 125.

33 M. Slaughter, 'A Global Community of Courts', Harvard International Law Journal 44 [2003], 191.

34 M. Slaughter, 'A Typology of Transjudicial Communication', University of Richmond Law Review, 29 (1994), 99 ff.

35 P.W. Almeida, 'The Asymmetric Judicial Dialogue between the ICJ and the IACtHR: An Empirical Analysis', Journal of International Dispute Settlement, 11 (2020), 1.

36 C. L'Heureux-Dubè, 'The Importance of Dialogue', cit., 17.

37 B. Markesinis and J. Fedtke (eds), Giudici e diritto straniero: La pratica del diritto comparato (Il Mulino, Bologna, 2009), 17.

38 S. Cassese, 'La funzione costituzionale dei giudici non statali: Dallo spazio giuridico globale all'ordine giuridico globale', Rivista trimestrale di diritto pubblico, fasc. 3 (2007), 609 ff. and id., I tribunali di Babele: I giudici alla ricerca di un nuovo ordine globale (Donzelli, Roma, 2009).

39 M. Cartabia, 'La Costituzione italiana e l'universalità dei diritti umani', Rassegna, 27 (2008), available at www.astrid-online.it (last visited 20 October 2021).

40 A. Barbera, 'Le basi filosofiche del costituzionalismo', in id. (ed.), Le basi filosofiche del costituzionalismo (Roma, Laterza, 1997), 3; S. Bartole, 'Costituzione e costituzionalismo nella prospettiva sovranazionale', Quaderni costituzionali, fasc. 3 (2009), 569 ff. 
There are a large number of articles documenting how judicial interactions take place between the CJEU and the ECtHR, ${ }^{41}$ between national courts from different jurisdictions and the CJEU ${ }^{42}$ between national courts and the ECtHR, ${ }^{43}$ between European and international courts ${ }^{44}$ and between national supreme or constitutional courts across Europe and around the world. ${ }^{45}$ However, there is no general agreement among academics and legal practitioners on how to name these types of interaction, and neither a uniform theory nor a definition. ${ }^{46}$ More recently terms such as "transnational judicial dialogue" ${ }^{47}$ and "conver-

41 See, e.g., L. Scheeck, 'Competition, Conflict and Cooperation between European Courts and the Diplomacy of Supranational Judicial Networks', GARNET Working Paper 23/07; S. Douglas Scott, 'A Tale of Two Courts: Luxembourg, Strasbourg and the Growing European Human Rights Acquis', CMLRev, 43 (2006), 3; K. Dzehtsiarou, T. Konstadinides, T. Lock and N. O'Meara, Human Rights in Europe: The Influence, Overlaps and Contradictions of the EU and the ECHR (Routledge, Oxon, 2014).

42 On interaction between constitutional courts and the CJEU, see G. Martinico, 'Judging in the Multilevel Legal Order: Exploring the Techniques of "Hidden Dialogue"', King's Law Journal, 21(2) (2010), 257.

43 A. Føllesdal, B. Peters and G. Ulfstein, Constituting Europe: The Court of Human Rights in a National, European, and Global Context (Cambridge University Press, Cambridge, 2013).

44 Consider, e.g., N. Lavranos, 'The CJEU's Relationship with Other International Courts and Tribunals', 6 September 2010, available at <http://papers.ssrn.com/sol3/ papers.cfm?abstract_id=1672727> (last visited 8 March 2012); Y. Shany, Regulating Jurisdictional Relations between National and International Courts (OUP, Oxford, 2007).

45 M. Bobek, S. Muller and S. Richards, 'Highest Courts and Globalisation'; T. Groppi and M. Ponthoreau, 'The Use of Foreign Precedents by Constitutional Judges'; J. Mendez, 'Constitutionalism and Transitional Justice', in Michel Rosenfeld and András Sajó (eds), The Oxford Handbook of Comparative Constitutional Law (OUP, Oxford, 2012), 1272.

46 For a legal perspective, see among others A.M. Slaughter, 'A Global Community of Courts', Harvard International Law Journal, 44 (2003), 191; A.T. Pérez, Conflicts of Rights in the European Union: A Theory of Supranational Adjudication (Oxford University Press, Oxford, 2009); A. Arnull, 'Judicial Dialogue in the European Union' in J. Dickson and P. Eleftheriadis (eds), Philosophical Foundations of European Union Law (Oxford University Press, Oxford, 2012), 109; for a political science perspective, see U. Sadl and Y. Panagis, 'The Force of EU Case Law: An Empirical Study of Precedential Constraint' (JURIX proceedings, The Foundation for Legal Knowledge Based Systems, 2015); U. Sadl and H. Palmer, 'Can Quantitative Methods Complement Doctrinal Legal Studies? Using Citation Network and Corpus Linguistic Analysis to Understand International Courts', Leiden Journal of International Law, 30 (2017), 327.

47 See M. Bobek, Comparative Reasoning in European Supreme Courts (OUP, Oxford, 2013); A. Slaughter, A New World Order (Princeton University Press, Princeton, 2009). 
sation' ${ }^{48}$ have also been employed.The term judicial dialogue, which so far seems to be the commonest term, ${ }^{49}$ seems restrictive and unable to grasp the whole range of contacts (either intentional or casual) between courts within the same Member State, between ones in different Member States, between national and the European supranational courts and between the two European supranational courts - the CJEU and the ECtHR - in the most comprehensive manner. Judicial dialogue entails an ongoing exchange of arguments in order to reach common understandings. ${ }^{50}$ Therefore, dialogue requires some sort of reciprocity among the judicial actors involved and it develops on a case by case basis over time. ${ }^{51}$ However, scholars noted that reciprocity and continuity over time occur rarely in practice. Other scholars criticise the idea of a judicial dialogue in itself, contending that dialogue is a common practice in political institutions but it is almost impossible among courts and judges,${ }^{52}$ that it is difficult to identify as it can often happen implicitly and not explicitly, ${ }^{53}$ and it requires an ongoing exchange of ideas, whereas in judicial practice there is more often a monologue rather than dialogue..$^{54}$

48 M. Claes, M. de Visser, P. Popelier and C. van de Heyning (eds), Constitutional Conversations in Europe: Actors, Topics and Procedures (Intersentia, Antwerp, 2013), 1.

49 A. Rosas, 'The European Court of Justice in Context: Forms and Patterns of Judicial Dialogue', EJLS, 1/2 (2007), 1; L.B. Tremblay, 'The Legitimacy of Judicial Review: The Limits of Dialogue between Courts and Legislatures', International Journal of Constitutional Law, 3 (2005), 617; F. Jacobs, 'Judicial Dialogue and the Cross-Fertilization of Legal Systems: The European Court of Justice', Texas International Law Journal, 38 (2003), 54.

50 Opinion of AG Bot delivered on 14 May 2014 in Case C-244/13 Ewaen Fred Ogieriakhi ECLI:EU:C:2014:323.

51 A. Torres Pérez, 'Judicial Dialogue and Fundamental Rights in the European Union: A Quest for Legitimacy', in G. Jacobsohn and M. Schor (eds), Comparative Constitutional Theory (Edward Elgar Publishing, Cheltenham, UK and Northampton, MA, USA, 2018), 104. As a consequence 'conversation' is also a wider category than 'dialogue' as it also includes instances where more than two actors are involved and interactions that have a more informal character or are not geared towards achieving a particular aim. For more details on 'conversations' as a form of judicial interaction, see M. Claes, M. de Visser, P. Popelier and C. van de Heyning, 'Introduction: On Constitutional Conversations', in id. (eds), Constitutional Conversations in Europe, Actors, Topics and Procedures (Intersentia, Antwerp, 2012), 1.

52 See B. De Witte, 'The Closest Thing to a Constitutional Conversation in Europe: The Semi-Permanent Treaty Revision Process' in P. Beaumont, C. Lyons and N. Walker (eds), Convergence and Divergence in European Public Law (Hart, Oxford, 2002), 137.

53 David S. Law and Wen-Chen Chang, 'The Limits of Global Judicial Dialogue', Washington Law Review, 86 (2011), 523.

54 A. Torres Pérez, 'Judicial Dialogue and Fundamental Rights in the European Union', cit., 104-5. 
This book instead endorses the term 'judicial interaction' in order to propose a category that reflects instances of interaction that may differ in intensity, outcome and typology, and that aims to construct a better interpretation of a legal norm without necessarily involving reciprocity or continuity over time. At the basic level, judicial interaction can be qualified as a sequence of judgments that refer to each other involving at least two courts and which are not necessarily in a hierarchical relation, with a shared intention of improving the practice of interpreting or reviewing a supranational norm. Therefore, judicial interactions embed a set of techniques used by courts and judges to promote coherence and coordination (or at least minimise the risk of conflicts) among different legal and judicial systems in safeguarding constitutional goods that are protected by various levels of governance. As a result, the cooperative contraposition $^{55}$ with foreign experiences is not interpreted as a transplant of law through case-law decisions, but instead as a form of dynamic flow of knowledge aimed at ensuring respect for the principles of the constitutional state of law. ${ }^{56}$

In addition to judicial interactions which take place through courts cross-referencing or comparative reasoning, whether explicit or implicit, over recent decades judges and courts around the world, and especially in the European Union, have increased their interaction, ${ }^{57}$ also directly through meetings, exchanges in workshops and conferences, delegations from one court to another, in institutional forms of cooperation ${ }^{58}$ or indirectly via online platforms, such as e-platforms and blogs. ${ }^{59}$ The judicial networks existing within the EU have contributed immensely to the increase in judicial interactions.

55 G. Zagrebelsky, La legge e la sua giustizia (Il Mulino, Bologna, 2008), 400.

56 E.F. MacGregor, 'What Do We Mean When We Talk about Judicial Dialogue? Reflections of a Judge of the Inter-American Court of Human Rights', Harvard Human Rights Journal, 30 (2017), 89.

57 Different types of classifications of the ways courts interact with each other are used in the literature: Frishman refers to three categories: face to face interactions, IT-based communication and cross-citations; see, O. Frishman, 'Transnational Judicial Dialogue as an Organisation Field', European Law Journal, 19 (2013), 739, 747; different types of classification have been used by A. Slaughter, 'Judicial Globalization', Virginia Journal of International Law, 40 (1999-2000), 1103, 1104; E. Lazega, 'Mapping Judicial Dialogue across National Borders: An Exploratory Network Study of Learning from Lobbying among European Intellectual Property Judges', Utrecht Law Review, 8 (2012), 115, 118.

58 For instance, European Judicial Training Network, Association of European Administrative Judges, Consultative Councils of European Judges, European Network of Councils for the Judiciary, Network of the Presidents of the Supreme Courts, European Network of Councils for the Judiciary.

59 This method of judicial cooperation is better developed in EU countries that recognise precedent as legally binding, e.g. the UK and Ireland, while civil law systems 
The great value of these informal meetings is that they offer national judges an opportunity to discuss and exchange views on the development of jurisprudence, tackling problems of interpretation and application in diverse areas of law, including European fundamental rights. Although these judicial interactions which take place between judges often materialise in cross-referencing (formal judicial interactions), this book does not consistently include in its analysis this type of judicial interactions, but will limit itself to providing anecdotal evidence, where relevant, to the main claims in the chapters.

\section{A TENTATIVE TAXONOMY OF JUDICIAL INTERACTIONS}

As mentioned above, judicial interactions may differ from each other in intensity, outcome and typology. This volume analyses judicial interactions in the EU and looks at three dimensions. First, it considers judicial interactions that habitually occur between national judges and the CJEU, most notably in the form of preliminary reference procedures, but also when national judges engage with the case law of the CJEU in other ways. We call this vertical judicial interaction. We also use this term for engagement by national judiciaries with ECtHR case law. Second, there will often be interactions between judges within the same Member State, which we call horizontal judicial interaction. Third, national judges may engage with the case law of other Member States' courts, which we call transnational judicial interaction. The term transnational judicial interaction can also describe interactions between the CJEU and the ECtHR. As we employ a broad understanding of the concept, judicial interaction can take various forms, of which the most important are: (1) the duty of consistent interpretation of national law with EU legal obligations as interpreted by the CJEU; (2) the preliminary reference procedure; (3) disapplication; (4) comparative reasoning with national legislation and jurisprudence from other Member States; and (5) mutual recognition of foreign judgments. ${ }^{60}$

This volume moves well beyond simply reflecting on vertical judicial interaction between national courts and the CJEU in the context of preliminary reference procedures. The main novelty of the book lies in the plentiful examples and case studies it offers regarding how courts in a Member State, through a transnational judicial interaction, work out how specific issues in the

(e.g. France and Romania) do not recognise legal precedent as stare decisis and so the use of national foreign judgments is less common.

${ }^{60}$ For a more in-depth analysis of 'Judicial Interaction Techniques', see M. Moraru, 'ACTIONES Module of Judicial Interaction Techniques' (2017), available at https:// cjc.eui.eu/wp-content/uploads/2019/03/D1.1.b-Module-2.pdf (last visited 20 October 2021). 
horizontal or sectoral application of the EU Charter can be best accommodated in their national judicial practices through the application of the EU's bill of rights.

The third dimension of judicial interaction discussed in the volume is transnational judicial interactions, which capture how national courts from different jurisdictions, and also supranational courts, chief among them the CJEU and the ECtHR, engage with each other's case law. The authors of this volume have engaged in more than just a jurisdiction by jurisdiction description of how the EU Charter is received by the national courts. The cross references, the contextualised discussion of the themes, the rich representation of case law selected in each chapter and commentaries will give the reader a compelling account of the three dimensional judicial interaction taking place in relation to the EU Charter. The volume reveals both positive outcomes, whereby national courts have made the EU Charter a real living instrument, but also a still limited impact of the Charter due to persistent lack of clarity regarding its scope of application (see Chapter 20) or the concrete added value of the Charter when there is already extensive EU secondary legislation in a particular sector (see Chapter 14), and a growing gap between the reach of the EU Charter and the needs of society in certain sectors (such as migration).

The premise of this book is that judicial interaction can answer complex legal questions relating to the implementation of the EU Charter. Several questions accordingly guide the assessment of judicial interaction in this volume.

- Have judicial interactions among courts contributed to making the multilevel system of fundamental rights one of mutual agreement or understanding?

- Have they contributed to an enhancement of fundamental rights or has this only been an incidental repercussion spinning off the enhancement of effective enforcement of EU law?

- How have policies and governance regimes been challenged and reconciled in courts, as spaces/forums of contestation?

- How have judicial interactions benefited national courts? Or have only some courts been benefiting from interactions?

- How have judicial interactions benefited the individual?

- Have judicial interactions contributed to transplanting fundamental rights standards across legal fields (e.g. right to be heard standards developed first in competition law, moved to smart sanctions and then to asylum and immigration)? Should there be a limit to these spillover effects? (Are remedies for the violation of the right to be heard in competition just for violation of the right to be heard in asylum and immigration?) 
To comprehensively address these questions, the book brings together leading authors from various backgrounds, including scholars, lawyers, judges and policy officers. The true hallmark of the entire volume is the extensive underlying research carried out in the framework of two European Commission-funded projects dedicated to judicial training, namely European Judicial Cooperation and Fundamental Rights Practice of National Courts - Unexplored Potential of Judicial Dialogue Methodology (JUDCOOP) ${ }^{61}$ and Active Charter Training Through Interaction of National Experiences (ACTIONES), ${ }^{62}$ which had the opportunity to train and involve a total of 600 national judges. The book includes several contributions addressing either horizontal or sectoral issues that will provide scholars and professionals with practical guidelines regarding the current and forthcoming challenges related to the application of fundamental rights.

Mirroring the experimentalist approach adopted in the abovementioned training projects, which triggered the creation of an epistemic community composed of academics and professionals, each contribution is written as a collaboration between one academic and a legal practitioner (i.e. a judge or a lawyer). The purpose is to provide the occasion for an exchange of expertise and knowledge, able not only to stimulate a deeper connection between theoretical analysis of rules and principles, but also their practical implementation in real life cases. The result is the provision of guidelines able to provide readers with reference to landmark cases and decisions at both the European and national levels. Along with each chapter, a comment by an academic or practitioner follows, highlighting the underlying principles of judicial interaction and their contribution to the application of the EU Charter.

${ }_{61}$ European Judicial Cooperation and Fundamental Rights Practice of National Courts - Unexplored Potential of Judicial Dialogue Methodology (JUDCOOP) financed by the European Commission and coordinated by the Centre for Judicial Cooperation. The results of the project are available at https://cjc.eui.eu/projects/european-judicial -cooperation-in-fr/ (last visited 20 October 2021).

${ }^{62}$ Active Charter Training Through Interaction of National Experiences (ACTIONES) funded by the European Commission and coordinated by the Centre for Judicial Cooperation, see more at https://cjc.eui.eu/projects/actiones/ (last visited 20 October 2021 ). 


\section{OVERVIEW OF THE CONTRIBUTIONS - EXPLORING THE OUTCOMES OF JUDICIAL INTERACTIONS ON THE APPLICATION OF THE EU CHARTER}

The Charter not only provides a written catalogue of fundamental rights but it also contains a set of rules known as 'general provisions' or 'horizontal clauses' concerning: the scope of application of the Charter (Article 51); the interpretation of the Charter's fundamental rights that 'correspond' to rights granted in the ECHR or 'result from the constitutional traditions common to the Member States' (respectively, Article 52, para. 3 and Article 52, para. 4); the different effects of the Charter's provisions that contain 'rights' or 'principles' (Article 52, para. 5); and its relationship with sources external to the EU legal order, notably domestic constitutions (Article 53).

Part I of the book provides an overview of the most relevant - and complex - issues emerging from the interpretation and application of horizontal provisions, ${ }^{63}$ taking into account the case law of the Court of Justice providing interpretation of them.

Judge Półtorak explores the limitations of the application of the rights and principles enshrined in the EU Charter by the Member States in order to highlight how the EU Charter may benefit, if not trigger, judicial interactions. She points out that the first step (although not necessarily the last one) for national courts is a clear qualification of the field of application, as enshrined in Article 51(1) of the Charter, which as a consequence sheds light on the scope of the obligation on the Member States to respect and apply the Charter but also to analyse the consequences of this obligation for national courts. Półtorak suggests that the question of the scope of application of the Charter should be distinguished from the question of its actual application in place of national constitutional rights and freedoms, and concludes that the Charter may operate in parallel with national fundamental rights - it may be put on standby and only step in when a national law does not guarantee an adequate level of protection or when the implementation of EU law is put in jeopardy.

Toggenburg’s commentary starts from Półtorak’s analysis and addresses three main questions. (1) How far does the 'field of application of Union law'

63 'General provisions' or 'horizontal clauses' concerning: the scope of application of the EU Charter (Article 51); the interpretation of the Charter's fundamental rights that 'correspond' to rights granted in the ECHR or 'result from the constitutional traditions common to the Member States' (respectively, Article 52, para. 3 and Article 52, para. 4); the different effects of the Charter's provisions that contain 'rights' or 'principles' (Article 52, para. 5); and its relationship with sources external to the EU legal order, notably domestic constitutions (Article 53). 
reach? (2) How many rights in the Charter provisions are rights in the strict sense, and of these how many are directly applicable between individuals? (3) What entails from the EU and the Member States being obliged to 'promote the application' of the Charter?

Zagorc and Kos address the interplay between constitutional values and the EU Charter. They describe how European values form and what their relationship with national constitutions is today, arguing that a decoupling has occurred forming a relatively independent EU value system which can now be employed against non-compliant Member States. As a result, their contribution suggests that the EU Charter should feature more prominently in legal conflicts between the EU and Member States which are essentially value-underpinned. The contribution then explores the use of the EU Charter which would be in line with the current constitutional setup of the EU, both within and outside its scope of application.

The comment by Lazzerini highlights the crucial role of the Charter as a bridge to national (constitutional) standards rather than as a pair of scissors. Lazzerini supports this argument by providing several examples emerging from the jurisprudence of the CJEU determining the standard of fundamental rights protection. Moreover, she shows that the Court's approach may become more open to contributions from Member States' constitutional standards thanks to the contribution of national courts.

The contribution by Judge Accetto assesses the impact of the EU Charter on the jurisprudence of national courts already vested with the duty of safeguarding fundamental rights - constitutional courts. He evaluates the import of the Charter as a recent addition to a relatively saturated field of laws and mechanisms of human rights protection, comprising not only the national constitutional orders but also the system under the ECHR and the development of human rights as general principles of EU law prior to the adoption of the Charter. His analysis takes into account a brief retrospective look at the 'constitutionalisation' of the EU legal order and the development of EU human rights law prior to the adoption of the Charter. Accetto then concludes that in the relatively short span of the first ten years the effects of the Charter are limited and indirect rather than dramatic and direct. Nevertheless, its formal and symbolic significance has contributed to the recently bolstered judicial interaction between the national apex courts and their European counterpart in reconciling overlapping fundamental rights regimes. Perhaps this indirect effect of the Charter may be the true catalyst of its long-term significance.

Halmai's comment investigates the original and the changed aims of the Charter's Article 51 to make sure that Member States respect fundamental rights, which is followed by a closer look at the right to effective remedy and fair trial guaranteed in Article 47 of the Charter. The conclusion of the commentary is that the Charter's effect on national constitutional jurispru- 
dence is more incremental and indirect than revolutionary, and it seems to be insufficient to protect fundamental rights, especially in Member States which do not comply with the values enshrined in Article 2 Treaty on European Union (TEU) in general, and the fundamental rights protection standards of the Charter in particular.

Podstawa and Gwizdak's contribution addresses one of the most sensitive issues emerging from the interplay between Articles 2 and 19(1) TEU, and Article $47 \mathrm{EU}$ Charter, and the principle of effectiveness of EU law. It addresses judicial independence, showing that its meaning is far from clear and uniform and its application far from straightforward. In particular, the contribution highlights that judicial independence in the CJEU case law involves three essential elements, namely the brewing conflict in the 'new' states of the European Union against the background of the judiciary reforms, the willingness of the CJEU to accept jurisdiction according to Article 19 TEU and finally the crucial role played by judicial interactions among national and European courts. Although the case law so far seems to align towards an increasing jurisdictional power in the EU legal order, according to the authors, the ongoing evolution does not conceal the fact that judges continue to seek support from the case law of the CJEU to make the standard of judicial independence more specific and less prone to manipulation.

Judge Zeller's commentary highlights that the standards adopted by the CJEU and other European bodies in addressing the weakness of EU legal systems vis-à-vis judicial independence are not always uniformly applied and interpreted. Zeller compares the Hungarian and Austrian legal systems, showing that elements pointed out as proofs of the erosion of rule of law in the Hungarian legal system are not so different from features that characterise the Austrian one, which, however, have never been criticised or contested at the EU level.

Ličková and Solanes Mullor focus their contribution on the right to be advised, defended and represented enshrined in Article 52(3) EU Charter. They assess whether the EU-specific articulation of fundamental-right standards remains coherent with their development before the ECtHR and concludes that cross-fertilisation between the two systems can work to some extent in both directions, as is shown by the ECtHR case law on Article 6(1)(c) ECHR and the regime of permissible restrictions on the right to legal advice under the Access to Lawyer Directive. The role of the EU Charter so far can only be acknowledged as a tool to interpret notions of EU law and to test the EU-law compatibility of Member States' actions when they implement EU law within the meaning of Article 51(1) of the Charter, although the number of cases decided by the CJEU on the meaning and specific implications of the provisions of the Access to Lawyer Directive so far remains rather limited, and many aspects therefore still remain to be explored. 
In the commentary by Judge Kargopoulos, the CJEU jurisprudence is analysed through the lens of the limits on approximation of criminal procedure laws set out in the Treaties (Article 5 TEU, Articles 67 and 82(2) TFEU). It is argued that often the CJEU does not properly reflect the limitations of the Treaties in its analysis, which risks overextending the application of secondary instruments in criminal proceedings, with the indirect effect of impairing national criminal justice systems and their formulations of defence rights, resulting in distrust of EU law rather than promoting mutual trust among Member States.

Judge McCloskey's contribution addresses the aetiology of the Charter and, in particular, its future influence in the post-Brexit United Kingdom. McCloskey affirms that the EU Charter, if deployed to its full potential, should emerge as one of the most powerful instruments of human rights protection in the globe and will progressively expose the folly of Brexit. The contribution concludes that the exile of the Charter after Exit Day will not be final and absolute. McCloskey supports this conclusion with several arguments, underlining in particular the fact that fundamental rights or principles of EU law, which exist irrespective of the Charter, will be retained in domestic UK law. Although there will be no right of action in domestic UK law after Exit Day based on a failure to comply with EU general principles, and courts will not be empowered to disapply domestic laws post-Exit Day on the basis that they are incompatible with EU general principles, McCloskey trusts the innovation and creativity of UK lawyers and judges: effective human rights protection, particularly in a country which has no constitution, will be heavily dependent on a strong rule of law culture.

Coutts's comment focuses on the roles the Charter will play in the UK legal system: a side-constraint on the exercise of state power; a source of legislative and judicial inspiration; and a means of underpinning transnational systems of cooperation. The analysis concludes that the exclusion of the Charter from retained EU law will remove the first but not the second, while making achievement of the third more difficult in any future relationship.

Part II of the book is dedicated to a selection of legal areas where the EU Charter has a relevant impact, namely migration and asylum, non-discrimination and consumer protection. The selection of these areas is based on the case law of the CJEU interpreting the EU Charter. Its impact is particularly evident in areas where EU rules touch on vulnerable categories of individuals, such as in the non-discrimination, migration and asylum fields. However, the 'presence' of the Charter is also more and more visible in fields in which, until now and for different reasons, the fundamental rights dimension has remained underdeveloped, such as consumer law.

Gião Hanek and Farkas's analysis starts from the limits emerging from the approach adopted by the EU non-discrimination acquis, which tends to 
be limited to the gender equality and non-discrimination directives, therefore showing a gaping difference between the level of protection accorded to certain groups and others. Therefore, the contribution broadens the perspective to secondary legislation, procedural and soft law measures pertaining to criminal forms of discrimination, yielding more nuanced insights. The contribution documents the emergence of a 'continuum of equality' between the civil and the criminal branches in EU anti-discrimination law, particularly through the Victims' Rights Directive. It shows that the EU Charter can play an important role in approximating EU norms to international human rights standards and offers strategies for addressing legislative deadlock to equalise protection across discriminated groups.

The comment presented by Attorney Bercea focuses on the CJEU's decision in Coman. It points out that despite the framing of the Romanian Constitutional Court's questions and the Advocate General's Opinion, the CJEU disregarded Article 21 of the Charter. This deliberate absence of reference is interpreted not as a form of deference to the national legal systems and judges but to the ECtHR. Accordingly, the CJEU's decision appears not only as a 'free movement' but also a 'human rights' case, as Article 21 of the Charter is discretely very much present in the decision as Article 14 ECHR is.

Grochowski and Taborowski's contribution addresses EU consumer law through the lens of its most important principle, namely the principle of effectiveness. This concept has recently been significantly reframed and reinvigorated in the CJEU case law on EU consumer law by two interconnected dynamics: the introduction of Article 47 EU Charter and the current debate over the axiological foundations of EU private law. Effectiveness has thus been elevated to a more prominent position, being situated at the intersection of policy and fundamental rights. The contribution then delves into the role of effectiveness in the protection offered by EU law to the consumer as a domain of dialogue between the CJEU and domestic courts, and adopts in this respect two focal points. It pays particular attention to the ways of proliferating the standard of effectiveness through instruments of judicial dialogue. In this regard the text adopts a two-pronged perspective. On the one hand, it seeks to identify the ways for domestic courts to bring the problem of effectiveness before the CJEU in the preliminary procedure. On the other hand, it attempts to understand the extent to which (and under what premises) the notion of effectiveness construed by the CJEU can be reflexively translated into domestic legal systems.

Iamiceli's comment highlights the multiple dimensions of effectiveness: the effectiveness of EU law and effet utile are boosted by effective judicial protection. The comment moves from these multiple dimensions and presents the different ways that other principles of EU law, such as proportionality and dissuasiveness, interact with them. Whereas proportionality enables a fair 
balancing when the right to an effective remedy needs to be limited against other fundamental rights or freedoms, dissuasiveness tends to serve effet utile, sometimes beyond the boundaries of effective judicial protection.

Moraru and Judge Clement's contribution delves into the role played by the EU Charter in asylum-, return- and visa-related hearing procedures through the lens of judicial interactions. Through an analysis of European and domestic cases spanning over a decade, the authors provide evidence of the crucial role played by judicial interaction in identifying which of the various EU legal sources of the right to be heard are applicable to asylum seekers, returnees and visa applicants at the domestic level. They continue by investigating how judicial interactions have contributed to the development of concrete standards for the conduct of administrative hearings. The chapter proceeds with an analysis of how judicial interactions have empowered domestic courts to shape new remedies for violation of the right to be heard outside the confines of EU secondary legislation and domestic procedural law directly on the basis of the EU law general principle of the right to defence and Article 47(2) EU Charter. Notwithstanding the positive impact of the EU Charter, the authors also identify shortcomings of judicial interaction for the uniform application of the EU fundamental right to be heard of asylum seekers and immigrants across the Member States.

Judge Flamini comments on a concrete case of judicial interaction, offering the perspective of a national judge who has to address the challenges of implementing a preliminary ruling from the CJEU in a context of divergent domestic jurisprudence and overlapping legal sources of fundamental rights. Although procedural law is a flexible means able to ensure respect for the fundamental right to international protection, it would remain a mere declaration of principle to affirm the fundamental nature of this right if effective procedural guarantees were not available to safeguard the substantive legal condition.

Part III of the book is dedicated to the role of judicial interactions in shaping remedies for fundamental rights violations on the basis of the EU Charter. The selection of these areas is based on the CJEU case law interpreting the EU Charter and extending its application in ever wider fields making it instrumental not only in settling individual violations of fundamental rights but also in shaping national legal systems to ensure respect of the EU Charter.

Bergström and Judge Sundberg investigate the principle of ne bis in idem, taking into account its explicitation in numerous international, regional and bilateral instruments. The interrelationship and parallel application of these legal instruments by a variety of courts may entail a number of legal challenges but also opportunities. In particular, Bergstrom and Sundberg start from the well-known Akerberg Fransson saga, showing its enormous impact on fundamental rights protection. At the same time, judicial interaction between national and European courts played a significant role during this saga. Then, 
the contribution aims to analyse the judicial interaction involved in the light of more recent developments before the CJEU and the ECtHR. As a result, the authors conclude that courts are instrumental not only in the settlement of individual disputes but also in changing the legal system.

Judge Ruiz Yamuza's commentary addresses the CJEU's $A Y$ decision, where the Court made some remarkable contributions concerning the construction of the ne bis in idem principle in Council Framework Decision 2002/584/JHA. The analysis allows a comparison with the approach adopted by the CJEU in the Akerberg Fransson case. In this case the axis on which the CJEU's analysis revolved was the relationship between administrative penalties and criminal law, whereas in $A Y$ it was criminal cooperation within the Area of Freedom, Security and Justice. Nevertheless, both cases are exponents of the CJEU's doctrine on the ne bis in idem principle and they present different areas of intersection.

Casarosa and Judge Sabato take stock of the increasing role of administrative enforcement in EU law through the allocation of regulatory and sanctioning powers to independent administrative authorities at the national level. The consequence is an institutional setting that relies on the interplay between administrative and judicial enforcement, which exerts an impact on the exercise of the right to an effective remedy. The contribution analyses the jurisprudence of the CJEU, showing that the time and methods of coordination between administrative and judicial enforcement are crucial from different perspectives. A first perspective is that of achieving effective judicial protection without undue delay and excessive cost of the proceedings. A second and equally important perspective is the role of judicial review in safeguarding fair trial guarantees. Administrative decisions are not outside the domain of effective judicial protection. Instead, they provide an added level of protection that should follow and comply with the same principles applicable to judicial ones. Only through interventions by national courts through preliminary rulings has the CJEU had the opportunity to identify the limits and conditions for specific institutional settings.

The comment by Judge Thoma analyses the branches of administration and the (administrative) judiciary, showing that in principle the relation between them seems clear at first sight: in a context of checks and balances it is up to the third power, the judiciary, to control the second one (the executive branch). But on a closer look this clear distinction is blurred: the directions of control may seem uneven and the range of control limited. The question posed by Thoma is what the essentials of a (administrative) judiciary are for it to be able to fulfil its function of control vis-à-vis the executive branch.

Casarosa and Judge Calò's contribution evaluates the recent legislative intervention on collective action, taking stock of the long and ongoing process that characterised the development of a European framework for this remedy. The 
contribution then compares the approach adopted by national and European courts both in terms of preventive remedies (e.g. injunctions) and in terms of reparatory remedies (e.g. class actions). In particular, the authors highlight the clear hierarchy between individual and collective action acknowledged in the CJEU's jurisprudence, which leaves collective actions playing only a complementary role. The authors affirm that this approach conflicts with the underlying objectives of collective remedy, namely the possibility of enhancing access to justice through the collective management of disputes addressing the same claim against the same plaintiff.

Vizzoni's comment starts its argument with the assumption that the mechanisms of collective redress ought to be applied with a clear view of the fundamental rights sphere from the perspective of maintaining a proper balance between effectiveness of protection and the requirements arising from the overall fundamental standards and guarantees existing in national legal systems. In order to evaluate the newly adopted European (and Italian) legal framework for collective redress, Vizzoni compares it with that available in antitrust law. The analysis allows a specific 'antitrust light' to be shed on collective mechanisms, disclosing some potentialities still in the direction of effective protection of the parties involved, but also some fallacies which deserve distinct consideration.

The vertical, horizontal or transnational judicial interactions analysed in this volume have produced concrete changes in the national legislation, on the relation between the domestic judiciaries, on the competences of the courts vis-à-vis the executive, and on domestic judicial doctrines, for the purpose of securing the supremacy and direct effect of EU law and the EU Charter. Ultimately, it is clear that judicial interaction has contributed first to a more coherent application of the EU Charter and, secondly, to an enhanced fundamental rights protection for individuals. They may have also offered national judges a cost-effective inspirational legal source for solving the difficult questions concerning the application of the EU Charter raised before them. ${ }^{64}$

64 The chapters in this volume were submitted around November 2020. 